Original Article

\title{
Effect of vaquejada exercise on the physiological and biochemical profiles of sporadic competitors and atletic horses
}

\author{
Richard Átila de Sousa1*, Gardênia Alves da Silva1, George Magno Sousa Rêgo², José Ribamar Gonçalves Neto², \\ Fernanda Patrícia Gottardi², Luciana Pereira Machado ${ }^{3}$ \\ 1 Universidade Federal do Piauí - Teresina, PI. \\ 2 Universidade Federal do Piauí - Bom Jesus, PI. \\ ${ }^{3}$ Universidade Federal da Fronteira Sul - Realeza - PR.
}

\section{A R T I C L E I N F O}

\section{Article history}

Received 15 July 2017

Received in revised form 27 October 2017

Accepted 03 November 2017

Keywords:

Equines

Exercise

Physiological biomarkers

\begin{abstract}
A B S T R A C T
The aim of this study was to analyze the effect of a cycle of three races as a part of the vaquejada test, on the serum biochemistry of horses that compete sporadically and athletic horses. Fourteen Quarter Horses was evaluated: group 1 (G1), with seven horses from the region that competed sporadically and group 2 (G2), with seven horses that competed regulary and were transported for $>200 \mathrm{~km}$. The physiological and serum biochemistry parameters were evaluated before exercise (M0) and after a cycle of three races of the vaquejada test: immediately after (M1); $30 \mathrm{~min}$ (M2) and 120 min (M3) after. Wilcoxon test was used to assess differences between the groups and Friedman test for moment effects, with a significance level of 5\%. There was increase in M1 compared with M0 for heart and respiratory rate in G2, and rectal temperature in G1. The exercise transiently changed most of the biochemical parameters, with significant diferences for uric acid in M1, albumin and lactate in M2, compared with M0, in G2. The metabolic response to exercise was different between the groups for the following variables: uric acid, total protein, albumin, unsaturated iron binding capacity, and transferrin saturation index. It was concluded that physiological and biochemical changes induced by Vaquejada are light, transiente, and within the normal range. The changes were more expressive in athletic horses that compete regularly and are transported, demonstrating the need for studies that establish specific training and management protocols for this category.
\end{abstract}

\section{INTRODUCTION}

In vaquejada competitions, two cowboys, mounted on their horses, have to gallop conducing a bull between the horses and guide it, such that the horse called "helper horse" accompanies the bull during the first $100 \mathrm{~m}$ of the track, when the cowboy on the horse called "pull horse" promove the bull tail traction and pull the bull down, between two delimited lines (LOPES et al., 2009; SANTIAGO et al., 2014).

Although vaquejada is popular in northeastern Brazil, the sanitary management of the animals involved and the conditions of the competition sites are quite poor (DIAS et al., 2013; LAGE et al., 2007). This exercise is typical of high intensity and short duration, characterized by a rapid sprint and that ends with an abrupt stop and lateral movement that promotes the bull downing in specific area, demanding a lot of physical strength of the equine. Several factors affect the performance and horse behavior in the competition, such as the man-animal, animal-environment (ambient temperature, humidity, pollution) relationships, as well as the handling and transportation system. These agents are often aggressors, promoting physiological reactions

\footnotetext{
*Corresponding author: richard@ufpi.edu.br
} 
in the animals (ARRUDA et al., 2015; GOMES et al., 2015; SANTIAGO et al., 2014;).

The vaquejada exercise is characterized as anaerobic, and lactate and glucose increase after the exercise (LOPES et al., 2009; SANTIAGO et al., 2014). Serum uric acid is also a possible candidate for evaluation of the anaerobic response to exercise. Its increase reflects the breakdown of adenosine triphosphate (ATP), used as energy source in intense exercise (EVANS; PRIDDLE; DAVIE, 2002), but no previous study has evaluated the concentration of uric acid in the contexto of vaquejada competition.

Muscle tissue is highly used during exercise, and muscle integrity can be assessed by the serum activity of creatine kinase (CK), aspartate amino transferase (AST), and lactate dehydrogenase (LDH) enzymes. Although the vaquejada exercise is characterized as a high intensity exercise, only in one study, by Sousa et al. (2014), a significant increase in the muscle enzymes was observed in local equine competitors, which was attributed to increased permeability instead of muscle damage.

There are few studies characterizing the biochemical alterations in equines during vaquejada, and considering the diversity of conditions in which the competitions are carried out, more information is needed to elucidate the metabolic alterations during this exercise. Machado et al. (2014) observed an increase in the serum transferrin as a positive response to the vaquejada exercise, the increase of transferrin is important to reduce the amount of free iron, which helps avoid the formation of reactive oxygen species, thus, preventing greater tissue injury, but the authors evaluated only the horses that competed in their source place. Gomes et al. (2015) observed the effect of transport for $250 \mathrm{~km}$, but only on clinical parameters, reporting the same response to exercise in local horses and transported ones. No previous study has evaluated the effect of competition regularity and long distance transport. The aim of this study was to evaluate the effect of a cycle of vaquejada exercise, on the physiological and biochemical profiles of pull horses, comparing horses that compete sporadically in their region and regularly competing horses who have been transported prior to the competition.

\section{MATERIAL AND METHODS}

The study was conducted during a vaquejada competition, in the municipality of Inhuma in the state of Piauí/Brazil. The climate of the locality is characterized as dry sub-humid (ANDRADE JÚNIOR et al., 2005). The protocol of the project was approved by the Ethics Committee on Animal Experimentation - CCEA of UFPI (074/11). We used 14 Quarter Horses, aged 4 to 10 years and weighing $439.57 \mathrm{~kg}$ (measured using weigh tape for horses). All horses competed in the pull category and were evaluated during a cycle of three races of the competition. The nutritional management was not evaluated, but all the owners reported that the animals received commercial ration and mineral supplementation.

The horses were divided into two groups: group 1 (G1), comprising seven horses (three male geldings, two stallions, and two females), aged 5 to 10 years $(7.4 \pm 1.9$ years), from the same municipality or neighboring municipalities (average distance of $79 \mathrm{~km}$ ), which participate sporadically in vaquejadas ( 2 to 3 vaquejadas per year), and do not receive daily training, and group 2 (G2), comprising seven animals (four stallions, two male geldings and one female), aged 4 to 10 years $(6.4 \pm 2$ years), from localities more than $200 \mathrm{~km}$ away (average distance $452 \mathrm{~km}$ ), which compete regularly (1 to 4 events per month during the competition period) and undergo training, although the owners do not refer to a specific protocol.

For evaluating the effect of a race cycle of the vaquejada competition, data collection of physiological parameters and blood samples for laboratory analysis were performed at the following moments: before exercise (M0), immediately after (M1), $30 \mathrm{~min}$ (M2), and $120 \mathrm{~min}$ (M3) after the three-race cycle. The temperature and relative humidity of the air were measured using a digital hygrometer, and registered along with the evaluations (Termo-Higrômetro AAKER®, AAKER LTDA, São Paulo, Brasil).

Heart rate (HR) was measured using a clinical stethoscope, positioned on the left side of the chest, and respiratory rate (RF) was verified by the observation of the movements of the costal gradil, both evaluated for 60 s. For rectal temperature measurement (TR), a clinical thermometer was used. Blood samples were obtained by puncturing the jugular vein, with a gauge needle $25 \times 8$ $\mathrm{mm}$ and using a cacuum adapter for collecting the blood into tubes (Vacutainer $\AA$ - Becton Dickinson-BD, Franklin Lakes, USA). In tubes containing $8 \mathrm{~mL}$ of the coagulation activator, $4 \mathrm{~mL}$ tubes with sodium heparin and 4 mLblood into tubes containing EDTA + sodium fluoride. Samples were centrifuged near Vaquejada Parque immediately after clot retraction, and the collected serum and plasma were immediately frozen at $-18{ }^{\circ} \mathrm{C}$ and then stored in an ultra-freezer $\left(-80^{\circ} \mathrm{C}\right)$ until analysis.

Biochemical analyses were performed on a semiautomatic biochemical analyzer (Doles D-250, Doles Reag. Equip. para laboratórios LTDA, Goiânia, Brasil), with the exception of the examinations related to the evaluation of iron metabolismo, which were carried out in a spectrophotometer (Espectrofotômetro digital SP22 - Bioespectro, Curitiba, Brasil). All assays were performed with commercial kits (Labtest $\AA$ - Lagoa Santa/MG, Brasil) and universal control serum (Qualitrol $1 \mathrm{H} 囚$, Labtest), following manufacturer's instructions. 
The assays included determination of serum uric acid concentration (methodology Enzyme - Trinder), total proteins (biuret method) and albumin (Bromocresol Green method), and the enzymatic activity of creatine kinase (CK) (Ultraviolet Kinetic method) and lactate dehydrogenase (LDH) (Pyruvate-lactate method). The globulins were obtained from the subtraction of the albumin concentration from the total protein concentration value. In plasma fluoride, the glucose (GOD-Trinder kinetic method) and lactate concentrations (Enzymatic-Trinder method) were determined. In heparin plasma, we measured the magnesium concentration (Magon Sulfonado method) and aspartate aminotransferase activity (AST) (Ultraviolet Kinetic method). Serum iron concentration $(\mu \mathrm{g} / \mathrm{dL})$ and unsaturated iron binding capacity (UIBC) $(\mu \mathrm{g} / \mathrm{dL})$ were estimated by the modified Goodwin method. The total iron binding capacity (TIBC) $(\mu \mathrm{g} / \mathrm{dL})$ was calculated as the sum of the UIBC values and serum iron concentration. The transferrin saturation index (IST) (\%) was obtained by multiplying serum iron by 100 and dividing this value by the UIBC. To obtain the transferrin concentration (TRF), the following formula was used: TRF $(\mathrm{mg} / \mathrm{dL})=$ TIBC $\mathrm{x}$ 0.7, following manufacturer's instructions (Labtest ${ }^{\circledR} \quad$ - $\quad$ Lagoa Santa/MG, Brasil).

For the statistical analyses, free software PSPP and R were used, with a significance level of $5 \%$ in all tests. In order to assess the differences between the post-exercise moments (M1, M2, and M3) and the basal moment (M0), Friedman test, followed by Kruskal-Wallis test for multiple comparisons, was applied. The Wilcoxon-Mann Whitney test was used to evaluate the differences between the groups (G1 and G2).

\section{RESULTS AND DISCUSSION}

The physiological parameters, heart rate (HR), respiratory rate (RR), and rectal temperature (RT) (Tab. 1) increased after a cycle of three races (M1) in comparison with the basal moment (M0), and the difference was significant $(\mathrm{p}<0.05)$ for HR and RR in G2 and RT in G1. There was no difference between groups. The HR in M0 was higher than expected for resting horses, however, similar values were observed for equines in vaquejada competitions in Piauí (GOMES et al., 2015) and are considered an adaptive response to the high ambient temperatures (FONSECA et al., 2014).

Table 1 - Median (minimum, maximum) of the physiological and climatic parameters of horses evaluated before exercise (M0), and immediately (M1), $30 \mathrm{~min}$. (M2) and $120 \mathrm{~min}$. (M3) after a three-race cycle of a vaquejada competition.

\begin{tabular}{cccccc}
\hline & & M0 & M1 & M2 & M3 \\
\hline Heart rate (bat./min) & G1 & $44(32 ; 72)$ & $80(40 ; 108)$ & $48(32 ; 100)$ & $44(36 ; 56)$ \\
& G2 & $44(34 ; 48)$ & $84(64 ; 104)^{*}$ & $56(44 ; 64)$ & $48(40 ; 80)$ \\
Respiratory rate (mov./min) & G1 & $32(16 ; 45)$ & $72(30 ; 96)$ & $48(32 ; 112)$ & $28(16 ; 64)$ \\
& G2 & $35(20 ; 44)$ & $76(48 ; 128)^{*}$ & $60(32 ; 152)$ & $32(24 ; 44)$ \\
Retal Temperature $\left({ }^{\circ} \mathrm{C}\right)$ & G1 & $37.1(36.4 ; 38.4)$ & $39.2(38 ; 40.8)^{*}$ & $38.6(38 ; 39.9)$ & $37.7(36.7 ; 38)$ \\
& G2 & $37.4(36.8 ; 38.5)$ & $39.6(37.4 ; 40.3)$ & $39.2(37.6 ; 40.1)$ & $37.9(37.2 ; 39.4)$ \\
Ambiental Temperature $\left({ }^{\circ} \mathrm{C}\right)$ & G1 & $25.5(23.5 ; 34.7)$ & $31.2(23.4 ; 35.1)$ & $31.7(23.3 ; 36.6)$ & $33(23.2 ; 35.6)$ \\
& G2 & $29.3(23.5 ; 36)$ & $35.1(22 ; 36.6)$ & $33(22 ; 35.8)$ & $29.7(20.9 ; 36.3)$ \\
Relative Humidity $(\%)$ & G1 & $65(31 ; 73)$ & $52(48 ; 72)$ & $52(47 ; 74) \mathrm{a}$ & $46(37 ; 78)$ \\
Black Globe Temperature $\left({ }^{\circ} \mathrm{C}\right)$ & G2 & $65(45 ; 73)$ & $47(35 ; 70)$ & $43(35 ; 70) \mathrm{b}$ & $43(35 ; 78)$ \\
& G2 & $31.1(27.9 ; 39.2)$ & $36.6(22.7 ; 45.1)$ & $37.7(22.7 ; 45.1)$ & $32.5(20.7 ; 41.6)$ \\
Black Globe Humidity $(\%)$ & G1 & $66(31 ; 73)$ & $53(48 ; 71)$ & $53(47 ; 74)$ & $47(36 ; 77)$ \\
& G2 & $66(43 ; 73)$ & $47(36 ; 72)$ & $42(36 ; 72)$ & $42(36 ; 78)$ \\
\hline
\end{tabular}

G1 = Group 1- local horses that compete sporadically; G2 = Group 2 - athletic horses that were transported.

* Indicates values differing from M0 in the same group by Friedman test, followed by Krusk-Wallis multiple comparison test ( $p<0.05)$.

Different letters in the same column indicate significant differences between groups by Wilcoxon-Mann Whitney test $(\mathrm{p}<0.05)$.

The increase in HR after exercise was also verified by Santiago et al. (2014) in a simulation of the vaquejada exercise, and by Gomes et al. (2015) in horses competing in vaquejada as pull horses. This increase in cardiovascular activity is associated with the high intensity of physical exercise, which results in a higher cardiac output to supply the oxygen demand of the active muscles (ALONSO et al., 2013).

The increase in respiratory rate shortly after exercise in the present study was higher than that found by Santiago et al. (2014) in a simulation of the vaquejada exercise, 
and by Gomes et al. (2015) in Quarter Horses. The differences between the studies can be explained by the fact that they were performed at different locations, and the respiratory rate is a physiological parameter that varies according to temperature and relative humidity (FONSECA et al., 2014). In addition, even though the race has standard delimitation in all competitions, the equine speed is variable.

Rectal temperature variation was similar to the values reported by Santiago et al. (2014) and Gomes et al. (2015), who discussed that this parameter begins to decrease within average 20 to $30 \mathrm{~min}$ post-exercise in vaquejada, and should return to rest levels in up to 60 min.

In the present study, the return of the TR values to the resting values was more evident only at $120 \mathrm{~min}$ after the race in both groups, but was not evaluated at $60 \mathrm{~min}$.

Regarding environmental data, high temperatures and low humidity were observed, which are characteristic of the climate where the study was carried out (ANDRADE JÚNIOR et al., 2005) and are considered as factors that can affect the performance of the animals in vaquejada tests (FONSECA et al., 2014). The relative air humidity had a difference between the groups in M2 ( $p<0.05)$, but the effect of this difference in the physiological parameters was very discrete, as at that time, there was no significant difference between the physiological parameters of the animals in different groups.

The exercise promoted alterations in most biochemical parameters (Table 2 and 3), verified by the comparison of the post-exercise moments (M1, M2, and M3) with rest (M0), but the difference between moments was significant $(\mathrm{p}<0.05)$ only for uric acid (M1), albumin (M2), and lactate (M2), both in G2. There were differences between groups, for glucose, uric acid, total protein, and albumin $(\mathrm{p}<0.05)$.

The lactate values were higher in M0 compared with those observed by Lopes et al. (2009), possibly due to methodological differences or lack of adequate training.

There was a light and non-significant elevation in the median lactate concentration in M2 of G2, followed by reduction in M2 $(\mathrm{p}<0.05)$ in comparison with $\mathrm{M} 0$, with a return to baseline values $120 \mathrm{~min}$ post-test. Although G2 animals were regular competitors, their higher lactate values suggest inadequate conditioning to the degree of physical activity. Lopes et al. (2009) observed an increase of more than $130 \%$ in basal lactate at the end of a vaquejada competition, although they did not report the number of races that the animals performed and whether the horses participated in the pull or helper category. In a simulation of the vaquejada competition composed by a cycle of three races, Santiago et al. (2014) reported higher lactate values in pull horses at the end of the exercise, compared with those observed in the present study, but the same decline in the concentration was observed for the latter at $30 \mathrm{~min}$ after exercise. Piccione et al. (2010) also associated the reduction in lactate concentration with this period, which indicates a high rate of lactate removal from the blood in the first 30 min after exercise.

Plasma glucose concentration showed a light increase in M1, not significant and within the physiological limits similar to those observed by Santiago et al. (2014) after a cycle of three races. Lopes et al. (2009) observed the same behavior with elevation at the end of the competition, but with glucose levels lower than the present study since M0, which may be justified by the authors having performed serum determination instead of using fluoride plasma, the use of fluoride as glycolytic inhibitor prevents glucose consumption by red blood cells prior to plasma separation.

The metabolic effect of the vaquejada exercise on the glucose concentration was different between groups $(\mathrm{p}<$ 0.05 ), with higher glycaemia occurring in athletic horses in M1 and M3, in comparison with G1 in the same moments. The higher values in the athletic animals indicate that they probably had a greater effect of cortisol, because of the stress of displacement from their place of origin to the place of test and the effect of the exercise itself. The increase in cortisol and glucose after vaquejada competition was previously verified and attributed to exercise stress, transport, and inadequate condition of the competition sites (LOPES et al., 2009).

The horses of G1 had higher uric acid concentration than the athletic horses $(p<0.05)$ in M0. However, in G1, these values remained constant before and after the exercises, in a concentration similar to that reported by Santiago et al. (2013) for event horses in training. On the contrary, in the athletes, there was an elevation of uric acid in M1 compared with M0 ( $p<0.05)$, indicating that physical exertion during exercise was higher in this group. This is the first report of increased uric acid during the vaquejada exercise, indicating that this marker responds quickly after intense exercise.

Evans; Priddle; Davie (2002) also observed this elevation of uric acid in race horses after physical exertion and demonstrated that this occurs when lactate concentration during exercise presents values above 12 $\mathrm{mmol} / \mathrm{L}$, both biochemical parameters being correlated with anaerobic metabolism. Although, in the present study, we did not measure lactate during exercise, the increase in lactate and uric acid after exercise suggests na involvement of anaerobic metabolism during the exercise performed. 
Table 2 - Median (minimum, maximum) of the serum biochemical profile, before exercise (M0), and immediately (M1), 30 min (M2), and $120 \mathrm{~min}$ (M3) after a three-race cycle of a vaquejada competition.

\begin{tabular}{cccccc}
\hline & & M0 & M1 & M2 & M3 \\
\hline Lactate & G1 & $6.2(5.9 ; 6.4)$ & $6.5(2.6 ; 7.1)$ & $4.8(3.2 ; 6.6)$ & $5.9(5 ; 6.3)$ \\
mmol/L & G2 & $6.1(5.2 ; 6.5)$ & $7.0(2.0 ; 7.1)$ & $3.4(2.8 ; 5.7)^{*}$ & $6.0(3.2 ; 6.3)$ \\
Glucose & G1 & $87.3(60 ; 99.1)$ & $94.5(63.7 ; 118.7)^{\mathrm{a}}$ & $75.6(61.2 ; 140.9)$ & $79.4(74.2 ; 93.7)^{\mathrm{a}}$ \\
mg/dL & G2 & $93.2(65.9 ; 102.3)$ & $124.5(90.8 ; 155.7)^{\mathrm{b}}$ & $99.7(56.9 ; 159.1)$ & $88.8(82.5 ; 118.2)^{\mathrm{b}}$ \\
Uric Acid & G1 & $1.1(0.7 ; 1.4)$ & $1.2(0.6 ; 2.1)$ & $1.2(0.5 ; 2.9)$ & $0.9(0.5 ; 1.4)$ \\
mg/dL & G2 & $0.5(0.3 ; 1.3)^{\mathrm{b}}$ & $1.4(0.9 ; 1.7)^{*}$ & $1.0(0.6 ; 1.4)$ & $0.8(0.2 ; 1.5)$ \\
Magnesium & G1 & $2.0(1.2 ; 2.5)$ & $1.4(1.1 ; 1.7)$ & $1.3(1.0 ; 1.7)$ & $1.6(1.2 ; 2.5)$ \\
g/dL & G2 & $2.2(1.4 ; 2.6)$ & $1.5(1.3 ; 1.9)$ & $1.4(1.2 ; 2.2)$ & $1.7(1.4 ; 1.9)$ \\
AST & G1 & $137.9(107.5 ; 391.1)$ & $179.6(134.4 ; 483.3)$ & $164.1(128.0 ; 376.2)$ & $168.8(111.3 ; 202.6)$ \\
U/L & G2 & $191.8(156.5 ; 356.4)$ & $240.5(168.5 ; 470.3)$ & $204.8(169.8 ; 655.7)$ & $215.6(126.6 ; 482.3)$ \\
CK & G1 & $101.0(56.3 ; 331.0)$ & $195.6(93.8 ; 332.7)$ & $139.7(101.4 ; 392.5)$ & $128.2(78.2 ; 307)$ \\
U/L & G2 & $122.6(75.8 ; 218.8)$ & $168.7(55.3 ; 240.2)$ & $114.1(92.1 ; 198.4)$ & $122.6(97.3 ; 206.6)$ \\
LDH & G1 & $589.9(457.3 ; 933.9)$ & $676.2(425.1 ; 869.5)$ & $695.1(454.0 ; 945.0)$ & $623.2(362.9 ; 1024.7)$ \\
U/L & G2 & $536.3(483.6 ; 932.4)$ & $538.1(364.0 ; 871.0)$ & $616.6(351.4 ; 762.8)$ & $565.5(332.2 ; 1015.0)$ \\
Total Protein g/dL & G1 & $7.4(6.7 ; 9.6)^{\mathrm{a}}$ & $7.4(6.8 ; 8.0)$ & $7.3(6.6 ; 8.9)$ & $7.2(6.7 ; 8.0)$ \\
& G2 & $6.7(6.5 ; 7.4)^{\mathrm{b}}$ & $7.9(5.3 ; 8.4)$ & $7.3(5.1 ; 9.0)$ & $7.3(6.8 ; 7.6)$ \\
Albumin & G1 & $2.7(2.4 ; 3.7)^{\mathrm{a}}$ & $2.8(2.4 ; 3.0)$ & $2.7(2.4 ; 3.1)$ & $2.8(2.4 ; 3.5)$ \\
g/dL & G2 & $2.4(2.0 ; 2.8)^{\mathrm{b}}$ & $3.0(2.0 ; 3.4)$ & $2.8(2.6 ; 3.6)^{*}$ & $3.0(2.6 ; 3.7)$ \\
Globulin & G1 & $4.9(3.0 ; 7.2)$ & $4.8(4.0 ; 5.4)$ & $4.6(3.5 ; 5.8)$ & $4.4(3.9 ; 4.8)$ \\
g/dL & G2 & $4.5(4.0 ; 5.2)$ & $4.8(3.3 ; 5.3)$ & $4.5(2.3 ; 5.4)$ & $4.2(3.8 ; 4.4)$ \\
\hline
\end{tabular}

$\mathrm{CK}=$ Creatine kinase; AST = Aspartate aminotransferase; LDH = Lactate dehydrogenase; G1 = Group 1 - local horses that compete sporadically; G2 = Group 2 - athletic horses that were transported.

* Indicates differences from M0 in the same group by Friedman test, followed by Krusk-Wallis multiple comparison test ( $p<0.05)$.

Different letters in the same column indicate significant difference between groups by Wilcoxon-Mann Whitney test $(\mathrm{p}<0.05)$.

The plasma magnesium concentration presented only a slight non-significant reduction at the post-exercise moments in a similar way in both groups, remaining within the reference values suggested for horses competing in vaquejadas $(1.2-3.0 \mathrm{mg} / \mathrm{dL}$ ) (DIAS et al., 2013). This result differed from the findings of Santiago et al. (2014), who reported an elevation of magnesium 4 $\mathrm{h}$ after the simulation of a three-race cycle; in the present study, the animals were evaluated only for $2 \mathrm{~h}$.

The concentrations of muscle enzymes AST, CK, and LDH did not show significant differences between moments or between groups, showing only slight elevation in the post-exercise moments, similar to the results of Lopes et al. (2009) for CK and those of Santiago et al. (2014) for AST and CK in vaquejada horses. The LDH results were similar to the baseline values reported by Sousa et al. (2014) (715.7 $\pm 250.1 \mathrm{U} / \mathrm{L})$, however, in the present study, was not verified the same increase observed by these authors immediately after the first race (1283.9 \pm $422.4 \mathrm{U} / \mathrm{L}$ ). Muscle enzymes elevate rapidly and transiently soon after exercise, by physiologically increasing the permeability of muscle cells, proportional to the intensity of the exercise; on the other hand, late elevation indicates that the exercise promoted muscle damage, with a peak of CK between 3 to $6 \mathrm{~h}$ and AST between 12 and $24 \mathrm{~h}$ after exercise (THOMASSIAN, et al., 2007). The results of the present study confirm the alteration due to increased permeability occurring within the physiological limits, but do not exclude the possibility of muscular injury. Sousa et al. (2014) evaluated the effect of the vaquejada exercise up to $24 \mathrm{~h}$ after exercise and did not observe an elevation indicative of muscle injury.

There was a significant difference $(\mathrm{p}<0.05)$ between the groups for total proteins and serum albumin in M0, with higher values in G1. The median total protein was always within the normal range for vaquejada equines (6.0 to $8.0 \mathrm{~g} / \mathrm{dL}$ ), while albumin (2.5 to $3.8 \mathrm{~g} / \mathrm{dL}$ ) was discretely reduced in G2 (DIAS et al., 2013), which may reflect deficient nutritional management for the degree of requirement of equine horses that compete regularly. Albumin increased $(\mathrm{p}<0.05)$ in M2 in comparison with 
M0 in G2. Although not significant, there was also a slight increase in the concentration of total proteins after exercise in G2, this elevation of albumin reflects a loss of fluid during exercise. Lopes et al. (2009) did not observe a significant difference in the total proteins after vaquejada competitions. Later, Santiago et al. (2014) reported a protein increase after the simulation of a cycle of three vaquejada races in the pull and helper horses, and observed mild dehydration in the helper horse category.

In both groups, the animals had mean basal (M0) values of serum iron, UIBC, TIBC, and IST within the range of normal for the species, however the minimum values of the iron concentration of G2 were below the reference (120 a $210 \mu \mathrm{g} / \mathrm{dL}$ ) (MACHADO et al., 2010) (Tab. 3), suggesting a deficient management in these animals in comparison with the degree of requirement. Serum iron concentration in horses may be influenced by several factors, including dietary availability and the presence of an inflammatory process that may lead to iron sequestration (ABRAMOVITC; PARRA; FERNANDES, 2014). A more intensive study to evaluate ferritin serum levels could elucidate the iron stores in these animals (MACHADO et al., 2010).

Table 3 - Median (minimum, maximum) of the biochemical parameters of evaluation of iron metabolism in horses evaluated before exercise (M0), and immediately (M1), $30 \mathrm{~min}$ (M2), and $120 \mathrm{~min}$ (M3) after a three-race cycle of a vaquejada competition.

\begin{tabular}{cccccc}
\hline \multicolumn{7}{c}{ M0 } & M1 & M2 & M3 \\
\hline Serum Iron & G1 & $160.2(135.5 ; 279.6)$ & $193.5(173.1 ; 364.5)$ & $168.8(101.1 ; 286.0)$ & $180.6(118.3 ; 359.1)$ \\
$\mu \mathrm{g} / \mathrm{dL}$ & G2 & $137.6(107.5 ; 234.4)$ & $172.0(57.0 ; 218.3)$ & $134.4(69.9 ; 206.4)$ & $166.7(52.7 ; 211.8)$ \\
UIBC & G1 & $198.3(152.5 ; 302.8) \mathrm{a}$ & $191.7(116.6 ; 314.8) \mathrm{a}$ & $162.3(112.2 ; 293.0)$ & $211.3(126.4 ; 330.1)$ \\
$\mu \mathrm{g} / \mathrm{dL}$ & G2 & $260.3(245.1 ; 317.0) \mathrm{b}$ & $275.6(197.2 ; 434.6) \mathrm{b}$ & $253.8(204.8 ; 378.8)$ & $257.1(201.5 ; 325.7)$ \\
TIBC & G1 & $390.8(310.6 ; 582.3)$ & $385.2(338.4 ; 578.2)$ & $361.2(225.3 ; 538.1)$ & $404.4(300.2 ; 525.8)$ \\
$\mu \mathrm{g} / \mathrm{dL}$ & G2 & $414.7(352.6 ; 540.5)$ & $415.6(374.0 ; 606.6)$ & $403.5(343.9 ; 480.6)$ & $378.4(352.8 ; 439.0)$ \\
IST & G1 & $48.0(40.1 ; 57.2) \mathrm{a}$ & $48.8(40.6 ; 75.8) \mathrm{a}$ & $45.5(41.9 ; 55.7) \mathrm{a}$ & $44.6(35.4 ; 68.3)$ \\
\% & G2 & $32.9(26.5 ; 43.4) \mathrm{b}$ & $31.5(15.2 ; 52.5) \mathrm{b}$ & $31.8(15.6 ; 50.2) \mathrm{b}$ & $39.0(13.9 ; 51.2)$ \\
Transferrin & G1 & $273.6(217.4 ; 407.7)$ & $269.6(236.9 ; 404.7)$ & $252.8(157.7 ; 376.7)$ & $283.1(210.1 ; 368.1)$ \\
mg/dL & G2 & $290.3(246.8 ; 378.4)$ & $290.9(261.8 ; 424.6)$ & $282.5(240.7 ; 336.4)$ & $264.9(247.0 ; 307.3)$ \\
\hline
\end{tabular}

UIBC = unsaturated iron binding capacity; TIBC = total iron binding capacity; IST = transferrin saturation index; G1 = Group 1 - local horses that compete sporadically; G2 = Group 2 - athletic horses that were transported.

*Indicates differences from M0 in the same group by Friedman test, followed by Krusk-Wallis multiple comparison test ( $<<0.05)$.

Different letters in the same column indicate significant difference between groups by Wilcoxon-Mann Whitney test $(p<0.05)$.

Serum iron, TIBC, and transferrin were not significantly different between the times or groups. However, there was a tendency of increase in serum iron concentration after exercise. When there is a real increase in serum iron, there is a concomitant increase in IST and a reduction in UIBC, which was not observed in the present study, as the IST remained constant. The increase in serum iron without IST alteration suggests a false elevation, which can be explained by hemoconcentration (MACHADO et al., 2010).

Smaller IST values were observed at moments M0, M1, and M2 in G2 and higher UIBC was observed in M0 and $\mathrm{M} 1$, in comparison with the same G1 moments. These results confirm the lower concentrations of iron in G2, although there was no significant difference between groups for serum iron. The, higher iron demand in this group is suggested to be due to the greater participation routine in competitions and displacements over long distances.
These findings are, in part, similar to those of Abramovitc; Parra; Fernandes (2014), who observed a decrease in serum iron and transferrin saturation, accompanied by an increase in TIBC 30 min after intense short-term exercise in horses competing in turf tests, and correlated this drop with an increase in the iron requirement in these animals.

Although G2 animals competed regularly, they demonstrated biochemical changes, suggesting insufficient physical conditioning and/or nutritional management for the degree of physical activity and transport stress, reinforcing the need for studies that develop training protocols and specific nutritional management for horses who compete in vaquejada.

The present study represents a picture of reality for the competitions in interior Northeast cities, and should be interpreted within the limitations of the lack of standardization of management among animals and differences in exercise intensity. 
Studies with simulation of the vaquejada test exclude these biases, however, they do not represent the collective effects that occur in a real competition.

\section{CONCLUSION}

For horses used in the pull category, the vital parameters changed only as physiological adaptations, after a cycle of three runs in the vaquejada competition. The biochemical profile alterations were discrete, transiente, and within the physiological limits. Horses that competed regularly and underwent transportation showed more expressive biochemical changes, demonstrated mainly by higher values of uric acid and glucose after exercise, compared with horses that compete sporadically close to their place of origin. It is suggested that the management and training given to these animals are insufficient to meet the demands of athletic horses who compete regularly, thus, warranting further studies.

\section{ACKNOWLEDGMENTS}

To Conselho Nacional de Desenvolvimento Científico e Tecnológico (CNPq) for the financial support to carry out the research (462380/2014-9), the clinic Criar Centro Veterinário and to LASAN - Laboratório de Sanidade Animal da Universidade Federal do Piauí - Campus Ministro Petrônio Portela, Teresina - PI/Brazil for providing the spaces for laboratory analysis.

\section{REFERENCES}

ABRAMOVITC, G.; PARRA, A. C.; FERNANDES, W. R. Variação de níveis séricos de ferro, da capacidade total de ligação do ferro e da saturação da transferrina em equinos de corrida, antes e após exercício físico. Revista Brasileira de Medicina Veterinária, v. 36, n. 9, p. 289-293, 2014.

ALONSO, J. M. et al. O treinamento nos valores da $\mathrm{V}_{200}, \mathrm{FC}_{\text {pico }}$ e distância percorrida de cavalos da raça Árabe e Crioula. Ciência Rural, v. 43, n. 4, p. 722-728, 2013.

ANDRADE JÚNIOR, A. S. et al. Classificação climática e regionalização do semi-árido do Estado do Piauí sob cenários pluviométricos distintos. Revista Ciência Agronômica, v. 36, n. 2, p. 143-151, 2005.

ARRUDA, S. S. B. et al. Clinical and blood gasometric parameters during Vaquejada competition. Pesquisa Veterinária Brasileira, v. 35, n. 11, p. 889-892, 2015.

DIAS, R. V. C. et al. Avaliação física e laboratorial da síndrome cólica de equinos em parque de vaquejada. Veterinária e Zootecnia, v. 20, n. 4, p. 658-672, 2013.

EVANS, D. L.; PRIDDLE, T. L.; DAVIE, A. J. Plasma lactate and uric acid responses to racing in pacing Standardbreds and relationships with performance. Equine Veterinary Journal, v. 34, n. 34, p. 131-134, 2002.

FONSECA, W. J. L. et al. Thermoregulatory characteristics of horses submitted to vaquejada competitions. Journal of Animal Behaviour and Biometeorology, v. 2, n. 2, p. 43-46, 2014.
GOMES, N. M. A. et al. Adaptações fisiológicas de equinos durante torneio de vaquejada. Enciclopédia biosfera, v. 11, n. 21, p. 36-49, 2015 .

LAGE, R. A. et al. Fatores de risco para a transmissão da anemia infecciosa equina, leptospirose, tétano e raiva em criatórios eqüestres e parques de vaquejada no município de Mossoró, RN. Acta Veterinária Brasílica, v. 1, n. 3, p. 84-88, 2007.

LOPES, K. R. F. et al. Influência das competições de vaquejada sobre os parâmetros indicadores de estresse em equinos. Ciência Animal Brasileira, v. 10, n. 2, p. 538-543, 2009.

MACHADO, L. P. et al. Metabolismo do ferro em equinos atletas. Ciência Rural, v. 40, p. 703-711, 2010.

MACHADO, L. P. et al. Resposta de fase aguda no exercício de vaquejada em equinos. In: XV Conferência Anual da Abraveq, 2014, Campos do Jordão. Anais... Programa e Resumos XV Conferência anual da Abraveq, 2014. p. 284-285.

PICCIONE, G. et al. Blood lactate levels during exercise in athletic horses. Comparative Clinical Pathology, v. 19, n. 6, p. 535-539, 2010.

SANTIAGO, J. M. et al. Hematologia e bioquímica sérica de equinos de concurso completo de equitação em treinamento. Arquivo Brasileiro de Medicina Veterinária e Zootecnia, v. 65, n. 2, p. 383-392, 2013.

SANTIAGO, T. A. et al. Blood biomarkers of the horse after field vaquejada test. Comparative Clinical Pathology, v. 23, n. 3, p. 769$774,2014$.

SOUSA, T. M. S. et al. Elevação transitória da atividade sérica das enzimas musculares em equinos após exercício de vaquejada. Ciência Veterinária nos Trópicos, v. 17, n. 3, p. 56, 2014.

THOMASSIAN, A. et al. Atividades séricas da aspartato aminotransferase, creatina quinase e lactato desidrogenase de equinos submetidos ao teste padrão de exercício progressivo em esteira. Brazilian Journal of Veterinary Research and Animal Science, v. 44 n. 3, p. 183-190, 2007. 